American University Washington College of Law

Digital Commons @ American University Washington College of

Law

Articles in Law Reviews \& Other Academic Journals

Scholarship \& Research

2010

\title{
The Impact of the Financial Crisis on Trade and Investment
}

Padideh Ala'i

American University Washington College of Law, palai@wcl.american.edu

Follow this and additional works at: https://digitalcommons.wcl.american.edu/facsch_lawrev

Part of the Banking and Finance Law Commons, and the International Trade Law Commons

\section{Recommended Citation}

Ala'i, Padideh, "The Impact of the Financial Crisis on Trade and Investment" (2010). Articles in Law

Reviews \& Other Academic Journals. 1237.

https://digitalcommons.wcl.american.edu/facsch_lawrev/1237

This Article is brought to you for free and open access by the Scholarship \& Research at Digital Commons @ American University Washington College of Law. It has been accepted for inclusion in Articles in Law Reviews \& Other Academic Journals by an authorized administrator of Digital Commons @ American University Washington College of Law. For more information, please contact kclay@wcl.american.edu. 
and Kazakhstan, Belgium and Montenegro, and India and Latvia, not to mention a number of FTAs. ${ }^{11}$

Moreover, the ongoing review of the U.S. model BIT ${ }^{12}$ has considered, at least in part, measures taken by national governments to prevent and mitigate the financial crisis, and the relationship between such measures and states' preexisting BIT obligations. The Advisory Committee's report (along with the various individual and collective statements) on the U.S. Model BIT review raised no fewer than three financial-crisis-related proposals, including:

- ensuring that any measures taken in response to the financial crisis are deemed consistent with investment treaty obligations.

- including a safeguard for balance-of-payments crises that is not subject to investorstate dispute settlement.

- excluding sovereign debt from "definitions" of an investment. ${ }^{13}$

The importance of this review of the U.S. Model BIT is underscored by the continuing negotiations between the United States and China over a potential U.S.-China bilateral investment treaty, the specifics of which are likely to be based on the new U.S. Model BIT. ${ }^{14}$

\section{Conclusion}

The implications of government intervention will no doubt continue to reverberate throughout the legal world, as well as throughout the financial market, for months and years to come. Although the impact of the crisis on investment regimes has so far attracted little attention, governments, regulators, and beneficiaries of intervention--as well as others who may feel discriminated against-will closely examine their respective rights and obligations.

Indeed, while we have yet to see an influx of ICSID or other investor-state cases based on the current crisis, it is likely too early to tell how many investors (if any) ultimately come forward with investment claims. If precedent crises are anything to go by, it may be several years before we can ascertain the full extent of the fallout from the current financial crisis.

\section{The Impact of the Financial Crisis on Trade and Investment}

\section{By Padideh Ala' 'i}

It is far too soon to tell what the precise impact of the 2008 global financial crisis (GFC) will be on trade and investment. First, it will take time for the full impact of the stimulus packages and crisis-related policies to be assessed by trading partners and private entities. Second, given the global nature of the crisis, governments may initially be reluctant to challenge governmental measures taken to assist domestic industries, particularly since in 2009 all major trading nations adopted measures designed to help domestic industries at home and in export markets.

\footnotetext{
${ }^{11}$ UNCTAD, Investment Policy Monitor, No. 2, Apr. 20, 2010.

12 Report of the Advisory Committee on International Economic Policy Regarding the Model Bilateral Investment Treaty Presented to the U.S. State DePartment, Sept. 30, 2009; Kevin P. Gallagher, US BITs and Financial Stability, Colum. FDI PeRsP. 19 (Feb. 23, 2010).

${ }^{13}$ Id.

${ }^{14}$ Evaluating a Potential US-China Bilateral Investment Treaty, EconOMIST INTELLIGENCE UNIT (Mar. 30, 2010).

"Professor of Law, American University, Washington College of Law.
} 
It is unreasonable to expect immediate recourse to dispute settlement as a result of the new GFC-related measures. The 2010 "recovery" could be a lull before another potentially stronger storm, or we may be in for a "double-dip" recession, as some have predicted. ${ }^{1}$ One important legacy of the GFC on which all can agree is the reality of a multi-polar world where the influence of the United States, together with confidence in the U.S. economy and currency, is in decline.

In 1989, as a recent graduate from law school, I had the opportunity to work on the Financial Institutions Reform and Recovery Enforcement Act of 1989 (FIRREA), which was enacted by the U.S. Congress in response to the savings and loan (S\&L) crisis. At that time, it was made clear to me by a very seasoned banking lawyer and a former Federal Reserve Board General Counsel that the financial condition of the U.S. banking industry would result in a crisis worse than what we had experienced with the U.S. savings and loan industry. It took almost twenty years for that prediction to materialize during which time the GlassSteagall Act that had separated commercial and investment banking in the United States was repealed, and we saw an unprecedented housing bubble. ${ }^{2}$ I can only conclude therefore that the GFC was foreseeable, many decades in the making, and will not be resolved quickly or painlessly.

\section{The Big Picture}

The 2008 financial crisis started in the United States and, given the interconnectedness of our global economy, very quickly became a global crisis. It resulted in the sharpest trade contraction ever recorded and the deepest cut in trade levels since the Great Depression. ${ }^{3}$ Between the fourth quarter of 2007 and the second quarter of 2008, world merchandise imports fell by 36 percent, negatively affecting every nation. ${ }^{4}$ In sum, by the end of 2009 , three years of trade expansion were eliminated and the world GDP fell by 2.2 percent. $^{5}$ Similarly, there was a decrease of 39 percent in global FDI flows in 2009 that affected all countries and all FDI components. ${ }^{6}$ FDI inflows to developing countries declined by 35 percent in 2009 after six years of uninterrupted growth in FDI flows. ${ }^{7}$

The response of governments to the crisis was to implement stimulus packages. These packages contain aspects that are likely to be inconsistent with the WTO commitments of the nations involved. Pascal Lamy, the Director General of the WTO, has been surprisingly muted in his criticism of the stimulus packages and has in fact applauded them in his general description of government action, which can only be a reflection of the severity of the current crisis and its detrimental effect on the volume of world trade. ${ }^{8}$ Lamy has stated that while the crisis has resulted in "slippage" with more trade restrictions in 2009 than prior years,

\footnotetext{
${ }^{1}$ Nouriel Roubini, Beware of a Double-Dip Recession, FoRBEs.com (Mar. 10, 2010), http://www.forbes.com.

${ }^{2}$ The Glass-Steagall Act was passed as part of the reaction to the collapse of the U.S. commercial banking system in early 1933. It sought to reduce the incentives for banks to engage in risky behavior by separating commercial and investment banking.

${ }^{3}$ OECD, UNCTAD, and WTO SECRETARIATS, REPORT ON G20 TRADE AND INVESTMENT MEASURES: SEPTEMBER 2009-FEBRUARY 2010 (Mar. 8, 2010), available at http://www.wto.org.

${ }^{4}$ See id. at 10 .

${ }^{5}$ Id.

${ }^{6}$ See id. at 19.

${ }^{7}$ UNCTAD, Fourth Global and Regional FDI Trends in 2009, 2 GLOBAL INVESTMENT TRENDS MonITOR (Jan. 19, 2010), available at http://http://www.unctad.org/en/docs/webdiaeia20101_en.pdf.

${ }^{8}$ WTO Secretariat, Overview of Developments in the INTERnational Trading Environment, ANNuAL REPORT BY THE DIRECTOR GENERAL 2 (2009), available at http://www.wto.org.
} 
protectionism did not rise to levels that were feared. Lamy credits the international trading rules for putting the brakes on protectionist policies. I tend to agree with him.

On the investment side, the fourth quarter of 2009 and first quarter of 2010 saw a modest recovery in FDI. ${ }^{9}$ The inflows of most of the major developed countries, such as the United States, remain much lower than in 2007, and it is premature to see a rebound of any strength at this time. ${ }^{10}$ Economic growth and profits remain fragile and the dire economic situation in Greece has been a rude awakening.

\section{The Emerging Economies and the ENd of the ThIRd World}

In a recent speech, Bob Zoellick, the President of the World Bank, proclaimed the end of the Third World. ${ }^{11}$ He stated that while 1989 saw the end of the Second World with communism's demise, 2008 saw the end of what was known as the Third World. ${ }^{12}$ Today is the official inauguration of a multi-polar world where the emerging economies of the socalled BRICs (Brazil, Russia, India, and China) are the engines for growth. ${ }^{13}$ More importantly, the BRICs themselves have come to recognize their own power, and this psychological shift will have longstanding consequences even if we come out of the current financial crisis.

In 2009 Brazil, China, and India implemented fiscal stimulus packages comparable in size and scope to those implemented by developed nations. These governments have the financial capacity as well as political will to help their economies. Brazil implemented over $\$ 488$ billion to improve energy and transportation services, and to support social and urban projects aimed at improving the pool of affordable housing. It is estimated that a total of $\$ 567$ billion more will be invested in projects aimed at promoting domestic industry, infrastructure, and housing from 2009-2012..$^{14}$

In response to the financial crisis, China implemented a stimulus package that has been called the "mother of all stimulus packages" and, unlike other countries, China can afford to do the same in 2010. ${ }^{15}$ The Chinese government also benefits from being able to order Chinese banks to lend while other governments cannot. As part of its stimulus package, China is focusing on increasing domestic consumer demand. Governmental policies have reduced internal trade restrictions and provide subsidies, including fiscal and credit support, to small and medium-sized firms as well as certain industrial sectors, such as automobiles, steel, shipbuilding, textiles, machinery manufacturing, electronics, and information systems. ${ }^{16}$ Through tax rebates and subsidies to rural consumers, the Chinese government plans to provide home appliances to over 900 million rural residences! ${ }^{17}$

\footnotetext{
${ }^{9}$ FDI Faces Modest Recovery, Forbes.com (Jan. 26, 2010), http://www.forbes.com.

${ }^{10}$ UNCTAD, Fourth Quarter of 2009 and First Quarter of 2010, 3 GLOBAL INVESTMENT Trends MoNITOR (Apr. 26, 2010), available at http://www.unctad.org/en/docs/webdiaeia20104_en.pdf.

${ }^{11}$ Robert B. Zoellick, World Bank President, The End of the Third World? Modernizing Multilateralism for a Multipolar World, Address Before the Woodrow Wilson Center for International Scholars (Apr. 14, 2010), at http:// web.worldbank.org.

${ }^{12}$ Id.

${ }^{13}$ Alan Beattie, BRICS: The Changing Faces of Global Power, FIN. TIMEs (Jan. 17, 2010), available at http:// www.ft.com/cms/s/0/95cea8b6-0399-1 ldf-a601-00144feabdc0.html?SID=google.

${ }^{14}$ Trade Promotion Dep't of the Ministry of External Relations (MRE), Brazil: Investment OpportuNITIEs (2009). See also BrazilNet (Mar. 2009), http://www.braziltradenet.gov.br/ARQUTVOS/Publicacoes/Estudos/ PUBBrasilExteriorI.pdf.

${ }^{15}$ Carla Fried, Is China Building the Next Bubble? CBS News (Mar. 19, 2010), http://www.cbsnews.com/8300503983_162-503983.html?keyword=Stimulus+Package.

${ }^{16}$ Wen Jiabao, Report on the Work of the Government, XinhuaNet (Mar. 15, 2010), http://news.xinhuanet.com/ english2010/china/2010-03/15/c_13211657_2.htm.

${ }^{17}$ Id.
} 
India has provided three installments of governmental stimulus funding in 2009 calculated to help the Indian business sector by providing duty cuts and easy liquidity, interest rate reductions, reduction of cash reserve ratios for Indian banks, financing of infrastructure projects, instituting higher levels of food subsidy and export support through pre-post shipment export credit and government backed securities. ${ }^{18}$

In sum, today, the emerging economies have the financial capacity and ability to protect their domestic industries from the effects of the GFC and possibly lead the recovery.

\section{Financial Crisis and International Economic LaW}

In 2008 there were calls for a "new Bretton Woods" conference and reform of the Bretton Woods institutions-the IMF, the World Bank, and the WTO. In late 2009 IMF staff privately admitted that while the IMF coffers had been amply replenished, there was uncertainty regarding the mandate of the IMF and the neo-liberal policies it had promoted.

In contrast to the IMF, and even the World Bank, the WTO has not been receiving much attention during this crisis, except for G-20 declarations about continued commitment to the Doha round of trade negotiations. ${ }^{19}$ This is a mistake. First, the WTO has provided an institutional setting that restrains governments from being overtly protectionist in their trade policies. Second, the WTO Secretariat has spearheaded efforts to monitor the actions of the G-20 in the wake of the crisis in cooperation with UNCTAD and other agencies, and it has compiled the measures governments have taken and are taking in connection with the crisis. ${ }^{20}$ This emphasis on transparency is one of the biggest contributions of the WTO to the future world order. Third, the dispute settlement of the WTO is the forum where the transnational impact of government stimulus packages will be assessed and cost-benefit analyses will be made. The WTO's unique panel and appellate body procedures have institutionalized the rule of law on a global scale, with extensive impact on domestic governance.

The stimulus packages have all potentially violated WTO agreements as well as other bilateral and regional ones. To date, the dispute settlement system of the WTO has not seen an influx of crisis-related cases, but such cases are inevitable. The frequency of such disputes will be dictated by complex geo-political factors. I hope that governments opt for resolving their disputes multilaterally and through the WTO, rather than unilaterally, although this will put enormous strain on the WTO system.

The WTO agreements most likely relevant to the crisis-related measures are the WTO Agreement on Trade in Services (GATS), ${ }^{21}$ the WTO Agreement on Subsidies and Countervailing Measures (SCM), ${ }^{22}$ and the Government Procurement Agreement (GPA). ${ }^{23}$ This is

\footnotetext{
${ }^{18}$ Gov't of Rajasthan, Office of the Commissioner of Industries, Different Economic Stimulus Packages for Easing Difficulties of Micro, Small and Medium-Sector Enterprises (2008), available at http://rajind.rajasthan.gov.in/Stimulus_Packages.pdf.

${ }^{19}$ G20 Leaders' Statement: The Pittsburgh Summit (Sept. 24-25, 2009), available at http://www.pittsburghsummit.gov/mediacenter/129639.htm.

${ }^{20}$ OECD, UNCTAD AND WTO SECRETARIATS, supra note 3.

${ }^{21}$ General Agreement on Trade in Services, Apr. 15, 1994, Marrakesh Agreement Establishing the World Trade Organization, Annex 1B, Legal Instruments-Results of the Uruguay Round, 33 ILM 1167 (1994).

${ }^{22}$ Agreement on Subsidies and Countervailing Measures, Apr. 15, 1994, Marrakesh Agreement Establishing the World Trade Organization, Annex 1A, Legal Instruments-Results of the Uruguay Round, 33 ILM 1195 (1994).

${ }^{23}$ Agreement on Government Procurement, Apr. 15, 1994, Marrakesh Agreement Establishing the World Trade Organization, Annex 4(b), Legal Instruments-Results of the Uruguay Round, 33 ILM 1125 (1994); see also Anne van Aaken \& Jürgen Kurtz, Prudence or Discrimination? Emergency Measures, the Global Financial Crisis and International Economic Law, 12 J. INT'L ECoN. L. 859 (2009).
} 
by no means an exhaustive list, and there are many other provisions (specifically, the national treatment principle) that may have been violated by GFC-related measures. Each of those agreements has specific exceptions that can be successfully invoked and will involve weighing and balancing of policies aimed at promoting domestic industries in difficult financial times with market access and non-discrimination goals of the multilateral system. In this balancing of interests, it is important to note that the WTO is no longer only concerned with promoting market access and non-discrimination through removal of governmental regulations and other measures. The WTO promotes regulations that are transparent, based on some objective criteria or standard, and that are applied in a non-discriminatory manner when possible. The WTO dispute settlement system in the past 15 years has much to teach the international system about the promotion of the rule of law, notwithstanding the fact that it also is in need of institutional reform so that it can adequately function in the 21 st century.

\section{IS THE CRISIS Really OVer?}

As stated earlier, it is not certain that recovery can be sustained. We have yet to address the fundamental reasons that led to this crisis, and our international organizations remain inadequate for our current needs. The 2010 recovery is uncertain, temporary, and fragile because it may have been the result of: (1) end-of-year inventory restocking, and (2) the continued impact of the financial stimuli designed by governments to increase access to credit. We shall see whether the recovery will continue when the warehouses are filled up and money from the financial stimulus packages dries up. ${ }^{24}$ The problems we face today are too complex and multifaceted to be addressed quickly, and the change in the balance of power between the United States and the new emerging economies, i.e., a multi-polar world, inevitably complicates cooperation and coordination between nations and governments at a time when such cooperation is most vital.

\footnotetext{
${ }^{24}$ World Trade: Recovery in Progress, Economist ONLINE (Mar. 2, 2010), http://www.economist.com/businessfinance/displaystory.cfm?story_id=15599453.
} 